\title{
Indoor air quality at different sites of a governmental hospital, Thailand
}

\author{
Pipat Luksamijarulkul ${ }^{1 *}$, Netchanok Somjai ${ }^{2}$, Noppanun Nankongnap ${ }^{3}$, Aranya Pataitiemthong ${ }^{4}$, Pornpimol Kongtip ${ }^{3}$ and Susan Woskie ${ }^{5}$ \\ ${ }^{1}$ Faculty of Health Sciences, Siam Technology College/Faculty of Public Health, Mahidol University, Bangkok, Thailand \\ ${ }^{2}$ Health Service System Development, Phrae Hospital, Phrae Province, Thailand \\ ${ }^{3}$ Department of Occupational Health and Safety, Faculty of Public Health, Mahidol University, \\ Bangkok, Thailand \\ ${ }^{4}$ Phutthasinnarat Hospital, Phitsanulok Province, Thailand \\ ${ }^{5}$ University of Massachusetts Lowell, MA, USA
}

\begin{abstract}
Objective: To assess indoor air quality at different sites of a governmental hospital in the northern region of Thailand.

Methods: This is a cross-sectional study of 208 indoor air samples collected from out-patient departments (OPDs), internal medical wards (IMWs), and intensive care units (ICUs) to investigate bacterial count (104 samples) and fungal count (104 samples). Groups or genus of isolated bacteria and fungi were preliminarily identified by Gram's stain and lacto-phenol cotton blue. Indoor temperature, relative humidity and $\mathrm{CO}_{2}$ level were measured in the same time. Outdoor air samples were collected for comparison. Data were analyzed using descriptive statistics.

Results: Mean and standard deviation of temperature in OPDs was $24.9 \pm 1.2^{\circ} \mathrm{C}$, that in IMWs was $31.0 \pm 0.3^{\circ} \mathrm{C}$, and that in ICUs was $25.8 \pm 0.9^{\circ} \mathrm{C}$ (outdoor $=31.4 \pm 0.1^{\circ} \mathrm{C}$ ). Relative humidity showed $60.4 \pm 3.6 \%, 63.8 \pm 1.9 \%$, and $60.9 \pm 3.0 \%$, respectively (outdoor $=59.9 \pm 0.9 \%$ ). Mean $\mathrm{CO}_{2}$ levels of $859.6 \pm 422.2 \mathrm{ppm}$., $320.3 \pm 28.2 \mathrm{ppm}$., and $408.1 \pm 13.1 \mathrm{ppm}$. (outdoor $=295.0 \pm 2.3 \mathrm{ppm}$.) were demonstrated. Means of bacterial counts were $329.8 \pm 207.6 \mathrm{cfu} / \mathrm{m}^{3} \mathrm{in} \mathrm{OPDs}, 376.7 \pm 80.2$ $\mathrm{cfu} / \mathrm{m}^{3}$ in IMWs, and $299.2 \pm 118.2 \mathrm{cfu} / \mathrm{m}^{3}$ in ICUs (outdoor air $=347.7 \pm 86.9 \mathrm{cfu} / \mathrm{m}^{3}$ ). Means of fungal counts were $146.7 \pm 82.3 \mathrm{cfu} / \mathrm{m}^{3}, 303.6 \pm 54.6 \mathrm{cfu} / \mathrm{m}^{3}$, and $215.7 \pm 80.0 \mathrm{cfu} / \mathrm{m}^{3}$, respectively (outdoor air $=301.2 \pm 85.3 \mathrm{cfu} / \mathrm{m}^{3}$ ). Approximately $12.3 \%, 11.5 \%$, and $29.5 \%$ of air samples collected from OPDs, IMWs and ICUs had bacterial counts higher than $500 \mathrm{cfu} / \mathrm{m}^{3}$, whereas, only 1 air sample collected from IMW had fungal count higher than $500 \mathrm{cfu} / \mathrm{m}^{3}$. Focusing on indoor air in ICUs, $47.6 \%$ and $19.1 \%$ of air samples had bacterial and fungal counts higher than $300 \mathrm{cfu} / \mathrm{m}^{3}$. The most common isolated bacteria and fungi were Staphylococcus spp., and Aspergillus spp., respectively.

Conclusion: This study revealed high bacterial contamination in indoor air at different sites of the hospital, especially in ICUs. The predominant isolated bacteria contaminated in air were Staphylococcus spp. which was one of common pathogens causing nosocomial infections. These are valuable data for developing interventions to improve indoor air quality which may affect the patient's health and the quality of working life of health care personnel, especially nurses in the hospital.
\end{abstract}

\section{Introduction}

Indoor air quality (IAQ) is one of major environmental problems related to human health. It can affect the health, comfort, well-being, and productivity of the building occupants [1]. Microbial indoor air comes from hundreds of bacterial and fungal species that grow indoors when sufficient moisture is available. Exposure to microbial contaminants is clinically associated with respiratory symptoms, allergies and asthma, and can affect the immunological system [2-4]. World Health Organization (WHO) estimates that $30 \%$ of the buildings may have IAQ related problems ${ }^{5}$. In 2007, a WHO working group on dampness and mould met to identify the main health risks due to excess moisture and microbial growth and contamination of indoor spaces, and to formulate WHO guidelines for protecting public health [6]. Dampness and mold growth in the home and workplace environment have been associated with adverse respiratory effects [6-8], and high concentration of bacteria or fungi in air indicated overcrowding or poor ventilation $[9,10]$. Preventing or minimizing persistent damp and microbial growth on interior surfaces and building structures is the most important means of avoiding harmful effects of indoor air on health [3].
Hospital is one of workplace areas contaminated with a variety of occupational hazards including infectious materials or contaminated equipments, blood and other body fluids from patients. Healthcare workers probably exposed to health hazards in the hospital environment, especially bioaerosol and to be at risk for infections $[10,11]$. Many medical procedures probably generate low particle size aerosols to be inhaled into the lungs of any exposed laboratory, dental and other healthcare personnel $[10,12,13]$. A recent study has shown that inadequate ventilation, inappropriate use of personal protective barriers, and inadequate disposal of biological wastes enhance risks of tuberculosis infection in hospital personnel $[12,14,15]$. Additionally, indoor air quality in the hospital may affect to hospital-acquire

${ }^{\star}$ Correspondence to: Pipat Luksamijarulkul, Faculty of Health Sciences, Siam Technology College/Faculty of Public Health, Mahidol University, Bangkok, Thailand, E-mail: pipatl@siamtechno.ac.th; pipat.luk@mahidol.ac.th

Key words: indoor air quality, microbial counts, $\mathrm{CO}_{2}$, temperature, relative humidity, hospital wards

Received: April 22, 2018; Accepted: May 22, 2019; Published: May 24, 2019 
infections, sick hospital syndrome and various occupational hazards to health among personnel and patients [16]. However, there is a limited study on microbial indoor air quality and microbial groups in a governmental hospital in the northern Thailand. The findings may be valuable to develop the preventive intervention for improving indoor air quality which may affect the patient's health and the quality of working life of health care personnel, especially nurses in this hospital.

\section{Materials and methods}

\section{Study design and study samples}

During May to July 2016, a cross-sectional design was carried out among a governmental hospital in the northern Thailand to investigate indoor air quality including bacterial and fungal counts, temperature, relative humidity, and $\mathrm{CO}_{2}$ level. A studied hospital is a provincial hospital with 750 patient-beds. This hospital is located near a busy traffic junction. In total 208 indoor air samples were collected from the different hospital sites including out-patient departments (OPDs), internal medical wards (IMWs), and intensive care units (ICUs) to investigate bacterial count (104 samples) and fungal count (104 samples). Eight outdoor air samples (4 samples for bacterial count and 4 samples for fungal count) were collected for comparison with indoor air assessment. Details are presented in Table 1. Additionally, temperature, relative humidity, and $\mathrm{CO}_{2}$ level were assessed in the same point and the same time of air sample collection.

\section{Methods of air sample collection and interpretation}

Indoor air in OPDs and outdoor air samples were collected during the hours from 9 a.m. to 3 p.m. on Friday. Indoor air samples in internal medical wards and ICUs were collected during the hours from 9 a.m. to 3 p.m. on Saturday, outdoor air samples were collected for comparison. All air samples were collected using the Millipore air tester. The Millipore air tester system is based on the Anderson principle, followed the active air sampling method [17], and uses a sieve with about 1,000 microperforations, which reduces the potential for overlapping colonies and minimizes the desiccation of the medium. The tester is small enough to be used in confined spaces, but powerful enough to sample up to 1000 liters in just seven minutes. In this study, 250 liters of air was collected. The plate count method was used to estimate bacterial or fungal counts. General bacteria were cultured in plate count agar at $37^{\circ} \mathrm{C}$ for $48 \mathrm{hrs}$, and general fungi were cultured in a
Sabouraud $4 \%$ dextrose agar, at room temperature, for 5 days with daily observation. After incubation, the bacterial and fungal colonies were counted and calculated to express as colony forming unit $/ \mathrm{m}^{3}\left(\mathrm{cfu} / \mathrm{m}^{3}\right)$ by the following formula:

Total counts (colony forming unit $/ \mathrm{m}^{3}$ or $\left.\mathrm{cfu} / \mathrm{m}^{3}\right)=[$ Total colonies $\mathrm{x} 1000] / 250$

The isolated colonies of bacteria and fungi were identified group or genus by gram stained and with lacto-phenol cotton blue dye following Larone's guide [18].

\section{Interpretation for microbial indoor air quality}

If the microbial count was more than $500 \mathrm{cfu} / \mathrm{m}^{3}$, it was an indication of overcrowding or poor ventilation following the recommended guideline of the American Conference of Governmental Industrial Hygienists (ACGIH) [9]. However, bacterial counts or fungal counts should be less than $300 \mathrm{cfu} / \mathrm{m}^{3}$ for general offices $[2,5]$.

\section{Ethical approval}

This study is a part of the research protocol submitted and approved by Ethics Committee for Human Research, Faculty of Public Health, Mahidol University and Ethics Committee of the studied hospital before data collection (COA. No. MUPH 2013-148 on 17 Oct, 2014).

\section{Data analysis}

Data were analyzed by computer program SPSS version 18 . The descriptive statistics including percentage, mean and standard deviation was used for describing bacterial and fungal counts.

\section{Results}

Indoor air quality: Temperature, relative humidity and $\mathrm{CO}_{2}$ concentration

A total sample of indoor air in a studied hospital included 57 samples from OPDs, 26 from IMWs, and 21 from ICUs. Results showed that mean temperature of OPDs was $24.9 \pm 1.2^{\circ} \mathrm{C}$, that of IMWs was $31.0 \pm 0.3^{\circ} \mathrm{C}$, and that of ICUs was $25.8 \pm 0.9^{\circ} \mathrm{C}$, respectively. For relative humidity, they were $60.4 \pm 3.6 \%, 63.8 \pm 1.9 \%$, and $60.9 \pm 3.0 \%$, respectively. And $\mathrm{CO}_{2}$ concentration, the means of $859.6 \pm 422.2 \mathrm{ppm}$., $320.3 \pm 28.2 \mathrm{ppm}$., and $408.1 \pm 13.1 \mathrm{ppm}$. were found in OPDs, IMWs, and ICUs, respectively. Details are shown in Table 2.

Table 1. Number of studied wards and indoor air samples collected among studied wards in a hospital

\begin{tabular}{|c|c|c|}
\hline Studied departments or wards & $\begin{array}{l}\text { No. of air samples for } \\
\text { Bacteria Fungi }\end{array}$ & Points of air sampling in departments or wards \\
\hline $\begin{array}{l}\text { OPDs } \\
1 \\
2 \\
3\end{array}$ & $\begin{array}{ll}18 & 18 \\
17 & 17 \\
20 & 20\end{array}$ & $\begin{array}{l}\text { Air samples were collected at the nurse station, medical examination room, patient observation room, } \\
\text { and patient waiting areas (central air conditioning system and sometimes with poor ventilation tested } \\
\text { by a smoke tube) } \\
\begin{array}{l}\text { Air samples were collected at the nurse station, and patient-bed section (naturally ventilated and } \\
\text { supplemented with electric ceiling fans) }\end{array}\end{array}$ \\
\hline $\begin{array}{l}\text { Medical wards } \\
\text { Female medical wards } \\
(1,2,3) \\
\text { Male medical wards }(1,2)\end{array}$ & $\begin{array}{ll}16 & 16 \\
11 & 11\end{array}$ & $\begin{array}{l}\text { Air samples were collected at the nurse station, and patient-bed section (central air conditioning } \\
\text { system) }\end{array}$ \\
\hline $\begin{array}{c}\text { ICUs } \\
1 \\
2 \\
3\end{array}$ & $\begin{array}{ll}7 & 7 \\
7 & 7 \\
7 & 7\end{array}$ & \\
\hline Total & 104104 & \\
\hline
\end{tabular}




\section{Indoor air quality: Bacterial and fungal counts in air samples}

For microbial indoor air quality, results showed means of bacterial counts $329.8 \pm 207.6 \mathrm{cfu} / \mathrm{m}^{3}$ in OPDs, $376.7 \pm 80.2 \mathrm{cfu} / \mathrm{m}^{3}$ in IMWs, and $299.2 \pm 118.2 \mathrm{cfu} / \mathrm{m}^{3}$ in ICUs (outdoor air $=347.7 \pm 86.9 \mathrm{cfu} / \mathrm{m}^{3}$ ). For fungal counts, they were $146.7 \pm 82.3 \mathrm{cfu} / \mathrm{m}^{3}, 303.6 \pm 54.6 \mathrm{cfu} / \mathrm{m}^{3}$, and $215.7 \pm 80.0 \mathrm{cfu} / \mathrm{m}^{3}$, respectively (outdoor air $=301.2 \pm 85.3 \mathrm{cfu} / \mathrm{m}^{3}$ ). Details are shown in Table 3 . When we analyzed microbial counts in detail classified into 3 levels, $<300 \mathrm{cfu} / \mathrm{m}^{3}, 300-500 \mathrm{cfu} / \mathrm{m}^{3}$, and $>500$ $\mathrm{cfu} / \mathrm{m}^{3}$, and compared with the recommended level of American Conference of Governmental Industrial Hygienist (ACGIH) committee recommendations $\left(\leq 500 \mathrm{cfu} / \mathrm{m}^{3}\right)$. It was found that $12.3 \%$ of air samples collected from OPDs, $11.5 \%$ collected from IMWs, and $29.5 \%$ collected from ICUs had bacterial counts higher than the recommended indoor air level of the ACGIH $\left(>500 \mathrm{cfu} / \mathrm{m}^{3}\right)$. As well as, $0.0 \%, 3.8 \%$, and $0.0 \%$ of air samples collected from OPDs, IMWs, and ICUs had fungal counts higher than the recommended indoor air level of the ACGIH $\left(>500 \mathrm{cfu} / \mathrm{m}^{3}\right)$. Focusing on indoor air in ICUs, $47.6 \%$ and $19.1 \%$ of air samples had bacterial and fungal counts higher than $300 \mathrm{cfu} / \mathrm{m}^{3}$. Details are shown in Table 4.

The isolated colonies of bacteria and fungi were identified into group or genus by gram stained and with lacto-phenol cotton blue dye. It was found that the most common bacteria was Staphylococcus spp. $(65.0 \%, 63.4 \%$, and $58.8 \%)$ found in OPDs, IMWs, and ICUs, whereas, the predominant fungi were Aspergillus spp. and septate hypha fungi (47.0\%, 42.5\%, and $48.6 \%$ VS $23.7 \%, 25.0 \%$, and $25.7 \%$, respectively). However, Penicillium spp. were found $22.5 \%, 27.5 \%$, and $22.9 \%$, respectively. Focusing on Staphylococcus spp., the predominant species was Staphylococcus aureus. Details are shown in Table 5.

\section{Discussion}

Poor indoor air quality in hospital may cause sick hospital syndrome including respiratory symptoms, skin symptoms, and nonspecific symptoms. It may lead to hospital-acquired infections in patients and healthcare personnel [21]. Hospital environments may be dynamic environments affected by weather conditions, indoor

Table 2. Mean \pm standard deviation of temperature, \% of relative humidity and $\mathrm{CO}_{2}$ concentration (ppm.) in air samples collected from studied hospital

\begin{tabular}{|l|c|c|c|c|}
\hline Studied wards & $\begin{array}{c}\text { No. of } \\
\text { samples }\end{array}$ & $\begin{array}{c}\text { Temperature } \\
\left({ }^{\circ} \mathbf{C}\right)\end{array}$ & $\begin{array}{c}\text { \% of Relative } \\
\text { Humidity }\end{array}$ & $\mathbf{C O}_{\mathbf{2}}$ (ppm.) \\
\hline OPDs & 18 & $25.3 \pm 1.3$ & $59.5 \pm 3.4$ & $779.3 \pm 104.3$ \\
1 & 17 & $23.9 \pm 0.8$ & $62.1 \pm 3.1$ & $1351.2 \pm 451.1$ \\
2 & 20 & $25.4 \pm 0.9$ & $59.8 \pm 3.7$ & $545.5 \pm 83.1$ \\
3 & 57 & $24.9 \pm 1.2$ & $60.4 \pm 3.6$ & $859.6 \pm 422.2$ \\
Total & & & & \\
Medical wards & & & & \\
FMW 1 & 5 & $31.2 \pm 0.4$ & $63.9 \pm 2.2$ & $267.4 \pm 20.8$ \\
FMW 2 & 5 & $31.8 \pm 0.2$ & $64.0 \pm 2.4$ & $275.0 \pm 20.7$ \\
FMW 3 & 6 & $29.6 \pm 0.4$ & $64.5 \pm 2.2$ & $419.7 \pm 61.2$ \\
MMW 1 & 5 & $31.6 \pm 0.1$ & $63.3 \pm 1.5$ & $328.4 \pm 14.8$ \\
MMW 2 & 6 & $30.9 \pm 0.4$ & $63.3 \pm 1.1$ & $310.8 \pm 23.6$ \\
Total & 26 & $31.0 \pm 0.3$ & $63.8 \pm 1.9$ & $320.3 \pm 28.2$ \\
& & & & \\
ICUs & 7 & $26.8 \pm 1.0$ & $59.0 \pm 3.5$ & $426.4 \pm 21.9$ \\
1 & 7 & $25.8 \pm 0.4$ & $63.4 \pm 1.8$ & $410.9 \pm 12.5$ \\
2 & 7 & $24.7 \pm 1.2$ & $60.4 \pm 3.6$ & $386.9 \pm 4.8$ \\
3 & 21 & $25.8 \pm 0.9$ & $60.9 \pm 3.0$ & $408.1 \pm 13.1$ \\
Total & & & & \\
\hline Outdoor & 2 & $31.4 \pm 0.1$ & $59.9 \pm 0.9$ & $295.0 \pm 2.3$ \\
\hline
\end{tabular}

Table 3. Mean \pm standard deviation of bacterial counts $\left(\mathrm{cfu} / \mathrm{m}^{3}\right)$ in air samples collected from studied hospital

\begin{tabular}{|l|c|c|c|}
\hline Studied wards & $\begin{array}{c}\text { No. of } \\
\text { Air samples }\end{array}$ & Bacterial counts & Fungal counts \\
\hline OPDs & 18 & $306.0 \pm 100.0$ & $152.4 \pm 89.5$ \\
1 & 17 & $304.2 \pm 77.1$ & $134.2 \pm 64.8$ \\
2 & 20 & $272.9 \pm 324.8$ & $152.2 \pm 91.3$ \\
3 & 57 & $329.8 \pm 207.6$ & $146.7 \pm 82.3$ \\
Total & & & \\
& & & \\
Medical wards & 5 & $423.2 \pm 76.8$ & $354.4 \pm 47.4$ \\
FMW 1 & 5 & $367.2 \pm 56.9$ & $374.4 \pm 33.7$ \\
FMW 2 & 6 & $370.4 \pm 63.0$ & $282.7 \pm 81.7$ \\
FMW 3 & 5 & $364.8 \pm 91.8$ & $282.4 \pm 46.4$ \\
MMW 1 & 5 & $376.7 \pm 80.2$ & $303.6 \pm 54.6$ \\
MMW 2 & 26 & & \\
Total & & $405.0 \pm 137.1$ & $162.6 \pm 50.8$ \\
& & $172.3 \pm 74.8$ & $208.7 \pm 91.1$ \\
ICUs & 7 & $320.4 \pm 142.8$ & $275.9 \pm 98.0$ \\
1 & 7 & $299.2 \pm 118.2$ & $215.7 \pm 80.0$ \\
2 & 7 & $347.7 \pm 86.9$ & $301.2 \pm 85.3$ \\
\hline 3 & 21 & 4 &
\end{tabular}

Table 4. Number and percentage of high level of bacterial and fungal counts $\left(\mathrm{cfu} / \mathrm{m}^{3}\right)$ in air samples collected from a studied hospital

\begin{tabular}{|c|c|c|c|c|c|c|c|}
\hline \multirow{2}{*}{$\begin{array}{l}\text { Studied } \\
\text { wards }\end{array}$} & \multirow{2}{*}{$\begin{array}{c}\text { No. of } \\
\text { Air } \\
\text { samples }\end{array}$} & \multicolumn{3}{|c|}{ Bacterial counts $\left(\mathbf{c f u} / \mathbf{m}^{3}\right)$} & \multicolumn{3}{|c|}{ Fungal counts $\left(\mathrm{cfu} / \mathrm{m}^{3}\right)$} \\
\hline & & $\leq \mathbf{3 0 0}$ & $301-500$ & $>500$ & $\leq \mathbf{3 0 0}$ & $301-500$ & $>500$ \\
\hline \multicolumn{8}{|l|}{ OPDs } \\
\hline 1 & 18 & 7 & 10 & 1 & 16 & 2 & 0 \\
\hline 2 & 17 & 9 & 7 & 1 & 16 & 1 & 0 \\
\hline 3 & 20 & 10 & 7 & 5 & 20 & 2 & 0 \\
\hline Total & 57 & $26(45.6)$ & $24(42.1)$ & $7(12.3)$ & $52(91.2)$ & $5(8.8)$ & $0(0.0)$ \\
\hline \multicolumn{8}{|l|}{$\begin{array}{l}\text { Medical } \\
\text { wards }\end{array}$} \\
\hline FMW 1 & 5 & 1 & 3 & 1 & 1 & 3 & 1 \\
\hline FMW 2 & 5 & 0 & 5 & 0 & 0 & 5 & 0 \\
\hline FMW 3 & 6 & 2 & 3 & 1 & 4 & 2 & 0 \\
\hline MMW 1 & 5 & 0 & 5 & 0 & 3 & 2 & 0 \\
\hline MMW 2 & 5 & 1 & 3 & 1 & 4 & 1 & 0 \\
\hline Total & 26 & $4(15.4)$ & $19(73.1)$ & $3(11.5)$ & $12(46.2)$ & $13(50.0)$ & $1(3.8)$ \\
\hline \multicolumn{8}{|l|}{ ICUs } \\
\hline 1 & 7 & 0 & 6 & 1 & 7 & 0 & 0 \\
\hline 2 & 7 & 7 & 0 & 0 & 6 & 1 & 0 \\
\hline 3 & 7 & 4 & 2 & 1 & 4 & 3 & 0 \\
\hline Total & 21 & $11(52.4)$ & $8(38.1)$ & $2(9.5)$ & $17(80.9)$ & $4(19.1)$ & $0(0.0)$ \\
\hline Outdoor & 4 & $0(0.0)$ & $3(75.0)$ & $1(25.0)$ & $1(25.0)$ & $2(50.0)$ & $1(25.0)$ \\
\hline
\end{tabular}

Table 5. Percentage of isolated bacteria and fungi classified by selected departments in a studied hospital

\begin{tabular}{|c|c|c|c|}
\hline \multirow{2}{*}{$\begin{array}{l}\text { Types of isolated } \\
\text { micro-organisms }\end{array}$} & \multicolumn{3}{|c|}{ Percentage of isolated micro-organisms by wards } \\
\hline & OPDs & Medical wards & ICUs \\
\hline Bacteria & $(\mathrm{n}=160$ colonies $)$ & ( $\mathrm{n}=90$ colonies $)$ & $(\mathrm{n}=80$ colonies $)$ \\
\hline Staphylococcus spp.* & $104(65.0)$ & $57(63.4)$ & $47(58.8)$ \\
\hline Gram negative rods & $37(23.1)$ & $21(23.3)$ & $22(27.5)$ \\
\hline Gram positive bacilli & $19(11.9)$ & $12(13.3)$ & $11(13.7)$ \\
\hline Fungi & $(\mathrm{n}=80$ colonies $)$ & $(\mathrm{n}=40$ colonies $)$ & $(\mathrm{n}=35$ colonies $)$ \\
\hline Aspergillus spp. & $38(47.5)$ & $17(42.5)$ & $17(48.6)$ \\
\hline Septate hypha fungi & $19(23.7)$ & $10(25.0)$ & $9(25.7)$ \\
\hline Penicillium spp. & $18(22.5)$ & $11(27.5)$ & $8(22.9)$ \\
\hline Others & $5(6.3)$ & $2(5.0)$ & $1(2.8)$ \\
\hline
\end{tabular}

*Most of them (51-58\% of Staphylococcus spp. in each ward) were S. aureus 
ventilation system in the hospital, season, number of patients, visitors and occupants, and out-door air contaminants [22]. This crosssectional study was only a short-term assessment of indoor air quality including indoor temperature, relative humidity, $\mathrm{CO}_{2}$ concentration, and microbial count (bacterial and fungal counts) in different hospital areas or wards. Additionally, a characterization of microbial genus or groups was preliminarily identified. The study found that mean temperature and mean relative humidity of OPDs was $24.9 \pm 1.2^{\circ} \mathrm{C}$ and $60.4 \pm 3.6 \%$, those of IMWs were $31.0 \pm 0.3^{\circ} \mathrm{C}$ and $63.8 \pm 1.9 \%$, and those of ICUs were $25.8 \pm 0.9^{\circ} \mathrm{C}$ and $60.9 \pm 3.0 \%$, respectively. The temperature and relative humidity in IMWs were higher than those in OPDs and ICUs due to no use of air conditioners in IMWs during indoor air study. They were open-air. For $\mathrm{CO}_{2}$ concentration, the means of $859.6 \pm 422.2$ ppm., $320.3 \pm 28.2 \mathrm{ppm}$., and $408.1 \pm 13.1 \mathrm{ppm}$. were found in OPDs, IMWs, and ICUs, respectively. The OPDs had the highest level of $\mathrm{CO}_{2}$ concentration due to the higher patients and their relatives waiting for seeking the doctors and treatment. This evidence supported the higher number of persons or activities having the higher $\mathrm{CO}_{2}$ concentration in the air environments and insufficient ventilation of indoor air, and it probably affected patients and hospital personnel who took a long time of exposure [20].

Results for microbial indoor air quality assessment showed that means of bacterial counts were $329.8 \pm 207.6 \mathrm{cfu} / \mathrm{m}^{3}$ in OPDs, $376.7 \pm 80.2$ $\mathrm{cfu} / \mathrm{m}^{3}$ in IMWs, and $299.2 \pm 118.2 \mathrm{cfu} / \mathrm{m}^{3}$ in ICUs. For fungal counts, they were $146.7 \pm 82.3 \mathrm{cfu} / \mathrm{m}^{3}, 303.6 \pm 54.6 \mathrm{cfu} / \mathrm{m}^{3}$, and $215.7 \pm 80.0 \mathrm{cfu} /$ $\mathrm{m}^{3}$ found in OPDs, IMWs, and ICUs, respectively. The higher levels of bacterial and fungal counts were found in air samples collected from IMWs probably due to the open-air wards on the time of air sample collection and the effect of the higher bacterial and fungal counts in outdoor air $\left(347.7 \pm 86.9 \mathrm{cfu} / \mathrm{m}^{3}\right.$ and $301.2 \pm 85.3 \mathrm{cfu} / \mathrm{m}^{3}$, respectively), whereas, the OPDs and ICUs used the air conditioners. The total number of microorganisms would be reduced after starting the air conditioning system in few minutes [21].

When we analyzed microbial counts in detail classified into 3 levels, $<300 \mathrm{cfu} / \mathrm{m}^{3}, 300-500 \mathrm{cfu} / \mathrm{m}^{3}$, and $>500 \mathrm{cfu} / \mathrm{m}^{3}$, and compared with the recommended level of American (ACGIH) $\left(\leq 500 \mathrm{cfu} / \mathrm{m}^{3}\right)$ and WHO ( $\leq 300 \mathrm{cfu} / \mathrm{m}^{3}$ for general officers). It was found that $12.3 \%$ of air samples collected from OPDs, $11.5 \%$ collected from IMWs, and 29.5\% collected from ICUs had bacterial counts higher than the recommended indoor air level of the ACGIH ( $\left.>500 \mathrm{cfu} / \mathrm{m}^{3}\right)$. As well as, $0.0 \%, 3.8 \%$, and $0.0 \%$ of air samples collected from OPDs, IMWs, and ICUs had fungal counts higher than the recommended indoor air level of the ACGIH $(>500$ $\mathrm{cfu} / \mathrm{m}^{3}$ ). However, $47.6 \%$ and $19.1 \%$ of air samples collected from ICUs had bacterial and fungal counts more than $300 \mathrm{cfu} / \mathrm{m}^{3}$. These evidences supported that hospital personnel and patients admitted in ICUs might be at risk for air-borne or droplet infections due to the poor ventilation in ICUs. Moreover, indoor air with bacterial or fungal counts more than $100 \mathrm{cfu} / \mathrm{m}^{3}$ might affect patients with immunosuppression [2,5].

The high level of bacterial counts indicated overcrowding or poor ventilation or unsanitary condition of indoor air in some areas of the studied wards [9.10]. Although most airborne bacteria and fungi do not present a health hazard, these micro-organisms may affect human health with a wide range of adverse health effects including respiratory infections, allergies and others in some individuals, especially susceptible persons, young children, elderly, and immune-compromised persons $[4,19,22,23]$. Several factors influenced the microbial load in indoor air, such as the number of occupants, the air conditioning systems, and the ventilation; and some physical factors including heat, temperature, and humidity were reported [24-26]. Occupants are a potential source of microorganisms as they shed the microorganisms from the skin and respiratory tract $[5,19]$. Additionally, Fungal counts in some areas, especially in IMWs were relatively higher levels. The control of temperature and relative humidity should be done. Temperatures below $16^{\circ} \mathrm{C}$ and above $25^{\circ} \mathrm{C}$ caused a reduction in the concentration of airborne fungi. Maintaining the relative humidity between 30-60\% would help control mold, dust mites, and cockroaches [27-29].

The isolated colonies of bacteria and fungi were identified group or genus. It was found that the most common bacteria were Staphylococcus spp. $(65.0 \%, 63.4 \%$, and $58.8 \%)$ found in OPDs, IMWs, and ICUs, likely the study of Sudharsanam et al (2012) [26] and Verde et al (2015) [16]. However, this bacterial air quality assessment and identification did not cover the anaerobic and higher bacteria. Whereas, the predominant fungi were Aspergillus spp. and septate hypha fungi (47.0\%, 42.5\%, and $48.6 \%$ VS $23.7 \%, 25.0 \%$, and $25.7 \%$, respectively). And Penicillium spp. were found $22.5 \%, 27.5 \%$, and $22.9 \%$, respectively. A survey of airborne fungi in buildings and outdoor environment in the United States (2002) found that Aspergillus spp. was the most common fungi [30] which was similar in the present study. The preventive interventions, such as improving the air ventilation and the biosafety to minimize risk of personnel injury and infections after this study should be considered. In addition, a longitudinal study, or surveillance might be done and other air quality indicators, especially, $\mathrm{PM}_{10}$ and $\mathrm{PM}_{2.5}$ levels should be included. The intervention program for reducing the microbial concentration in the air should emphasize the ventilation strategy, the cleaning program on surface environments, medical instruments and air conditioners in the studied wards.

\section{Conclusion}

This study revealed high bacterial contamination in different wards of a studied hospital. The predominant isolated bacteria and fungi contaminated in air samples were Staphylococcus spp. and Aspergillus spp., respectively. These are valuable data for developing interventions to improve indoor air quality which may affect the patient's health and the quality of working life of health care personnel, especially nurses in this hospital.

\section{Conflicts of interest}

We declare that we have no conflict of interest.

\section{Acknowledgments}

We would like to thank heads of 3 studied hospital wards for their help and cooperation during this study.

\section{References}

1. World Health Organization (2006) Preventing disease through healthy environments Towards an estimate of environmental burden of disease. WHO Press, Geneva: 1-106.

2. Zweers T (1992) Health and indoor climates complaints of 7043 office workers in 61 buildings in the Netherlands. Indoor Air 2: 127-136.

3. Górny RL, Dutkiewicz J (2002) Bacterial and fungal aerosols in indoor environment in Central and Eastern European countries. Ann Agric Environ Med 9: 17-23. [Crossref]

4. Luksamijarulkul P (2015) Air quality and older people. Asia J Public Health 6: 40-41.

5. World Health Organization (1990) Indoor air quality: Biological contaminants. QHO regional publications. European Ser 30: 385-374.

6. World Health Organization (2008) Development of WHO guidelines for indoor air quality: Dampness and mould. Report on a working group meeting. Bonn, Germany 17-18 October 2007. WHO Regional Office for Europe, Denmark.

7. McNeel SV, Kreutzer RA (1996) Fungi and indoor air quality. Health \& Environment Digest 10: 9-12. 
8. Szymanska J (2005) Evaluation of mycological contamination of dental unit water lines. Ann Agric Environ Med 12: 153-155.

9. Seitz TA (1989) NIOSH indoor air quality investigations 1971-1988. In: Weekes DM, Gammage RB. Proceedings of the indoor air quality, international symposium: The practitioner's approach to indoor air quality investigations. American Industrial Hygiene Association Ohio 163-171.

10. Bennett A, Parks S (2006) Microbial aerosol generation during laboratory accidents Subsequent risk assessment. $J$ Appl Microbiol 100: 658-663.

11. Vonesch N, Tomao P, Di Renzi S, Vita S, Signorini S (2006) [Biosafety in laboratories concerning exposure to biological agents]. G Ital Med Lav Ergon 28: 444-456. [Crossref]

12. Luksamijarulkul P, Khumsri J, Vatthanasomboon P, Aiumlaor P (2009) Improving tuberculosis infection control practice and microbial air quality in a general hospital after intervention. Asian Pac J Trop Med 2: 39-46.

13. Luksamijarulkul P, Kiennukul N, Vatthanasomboon P (2014) Laboratory facility design and microbial indoor air quality in selected hospital laboratories. Southeast Asian $J$ Trop Med Public Health 45: 746-755.

14. Deriemer K, Moreira FM, Werneck AM, Ueleres J (2000). Survey of mycobacteriology laboratory practices in an urban area with hyperendemic pulmonary tuberculosis. Int $J$ Tuberc Lung Dis 4: 776-783.

15. Luksamijarulkul P, Supapvanit C, Loosereewanich P, Aiumlaor P (2004) Risk assessment towards tuberculosis among hospital personnel: administrative control, risk exposure, use of protective barriers and microbial air quality. Southeast Asian J Trop Med Public Health 35: 1005-1011.

16. Cabo Verde S, Almeida SM, Matos J, Guerreiro D, Meneses M, et al (2015) Microbiological assessment of indoor air quality at different hospital sites. Res Microbiol 166: 557-563.

17. Pasquarella C, Albertini R, Dall'aglio P, Saccani E, Sansebastiano GE, et al. (2008) [Air microbial sampling: the state of the art]. Ig Sanita Pubbl 64: 79-120. [Crossref]

18. Larone DH (1995) Medically important fungi: a guide to identification. 3rd edition Washigton DC: American Society of Microbiology Press.
19. Douwes J, Thome P, Pearee N, Heedrik D (2003) Review bioaerosol, health effects and exposure assessment: Progress and prospects. Ann Occup Hyg 47: 187-200

20. Satish U, Mendell MJ, Shekhar K, Hotchi T, Sullivan D, et al. (2012) Is CO2 an indoo pollutant? Direct effects of low-to-moderate $\mathrm{CO} 2$ concentrations on human decisionmaking performance. Environ Health Pers 120: 1671-1677.

21. Vonberg RP, Gastmeier P, Kenneweg B, Holdack-Janssen H, Sohr D, et al. (2010) The microbiological quality of air improves when using air conditioning systems in cars. BMC Infect Dis 10: 146. [Crossref]

22. Luksamijarulkul P, Ratthanakhot Y, Vatanasomboon P (2012) Microbial counts and particulate matter levels in indoor air samples collected from a child home-care center in Bangkok, Thailand. J Med Assoc Thai 95(Suppl 6): S161-168.

23. Graham LM (2004) All I need is the air that I breath: outdoor air quality and asthma. Paediatr Respir Rev 5 Suppl A: S59-64. [Crossref]

24. Piecková E, Jesenská Z (1999) Microscopic fungi in dwellings and their health implications in humans. Ann Agric Environ Med 6: 1-11. [Crossref]

25. Klánová K (2000) The concentrations of mixed populations of fungi in indoor air: rooms with and without mould problems; rooms with and without health complaints. Cent Eur J Public Health 8: 59-61. [Crossref]

26. Sudharsanam S, Swaminathan S, Ramalingam A, Thangavel G, Annamalai R, et al (2012) Characterization of indoor bioaerosols from a hospital ward in a tropical setting Afr Health Sci 12: 217-225. [Crossref]

27. Norris TB, McDermott TR, Castenholz RW (2002) The long-term effects of UV exclusion on the microbial composition and photosynthetic competence of bacteria in hot-spring microbial mats. FEMS Microbiol Ecol 39:193- 209.

28. Mc Neel SV, Kreutzer RA (1996) Fungi and indoor air quality. Health Environ Dig 10: $9-12$

29. Gonçalves FL, Bauer H, Cardoso MR, Pukinskas S, Matos D, et al (2010). Indoor and outdoor atmospheric fungal spores in the São Paulo metropolitan area (Brazil): species and numeric concentrations. Int J Biometeorol 54: 347-355.

30. Shelton BG, Kirkland KH, Flanders WD, Morris GK (2002) Profiles of airborne fungi in buildings and outdoor environments in the United States. Appl Environ Microbiol 68: $1743-1753$.

Copyright: (C2019 Luksamijarulkul P. This is an open-access article distributed under the terms of the Creative Commons Attribution License, which permits unrestricted use, distribution, and reproduction in any medium, provided the original author and source are credited. 